\title{
Variations of ablation, albedo and energy balance at the margin of the Greenland ice sheet, Kronprins Ghristian Land, eastern north Greenland
}

\author{
THOMAS KONZELMANN \\ Department of Geography, Swiss Federal Institute of Technology, CH-8057 Zürich, Switzerland \\ Roger J. BRAITHWAIte \\ Gronlands Geologiske Undersogelse, DK-1350 Kobenhavn K, Denmark
}

\begin{abstract}
A meteorological and glaciological experiment was carried out in July 1993 at the margin of the Greenland ice sheet in Kronprins Christian Land, eastern north Greenland. Within a small area (about $100 \mathrm{~m}^{2}$ ) daily measurements were made on ten ablation stakes fixed in "light" and "dark" ice and were compared to each other. Simultaneously, the components of the energy balance, including net radiation, sensible-heat flux, latent-heat flux and conductive-heat flux in the ice were determined. Global radiation, longwave incoming radiation and albedo were measured, and longwave outgoing radiation was calculated by assuming that the glacier surface was melting. Sensible- and latent-heat fluxes were calculated from air temperature, humidity and wind speed. Conductive-heat flux in the ice was estimated by temperature-profile measurements in the uppermost ice layer. Net radiation is the major source of ablation energy, and turbulent fluxes are smaller energy sources by about three times, while heat flux into the ice is a substantial heat sink, reducing energy available for ice melt. Albedo varies from 0.42 to 0.56 within the experimental site and causes relatively large differences in ablation at stakes close to each other. Small-scale albedo variations should therefore be carefully sampled for large-scale energy-balance calculations.
\end{abstract}

\section{INTRODUCTION}

An ablation-climate study was made at the margin of the Greenland ice sheet in Kronprins Christian Land, eastern north Greenland (Fig. 1). The study was part of a 2 year programme on world sea-level changes supported by the European Community. The specific objective of the study was to collect data on climate, ablation, radiation and ice temperature to estimate the sources and sinks of the energy balance during the period of measurements (8-27 July 1993) and to compare conditions with those found in West Greenland (Braithwaite and Olesen, 1989, 1990).

The fieldwork was carried out at two study sites. One was located on the tundra in front of the ice sheet (base camp). The other was established on the ice sheet (glacier station). The glacier station was located about $300 \mathrm{~m}$ inland of the ice margin at an elevation about $50 \mathrm{~m}$ above the ground-level at the edge. The site was well-exposed without marked slope, i.e. it represents a large area close to the ice-sheet margin. The surrounding area was covered by hummocks about $0.5 \mathrm{~m}$ in height and $5 \mathrm{~m}$ in wavelength, i.e. the surface topography is rougher than the site in West Greenland (Camp IV; Fig. 1), where Ambach (1963) made energy-balance studies. The glacier station was a walk of only $10 \mathrm{~min}$ from the base camp and was visited several times daily during the experiment. The position of the glacier station was determined by the global positioning system (GPS) to be latitude $79^{\circ} 54^{\prime} 43^{\prime \prime} \mathrm{N}$ and longitude $24^{\circ} 04^{\prime} 25^{\prime \prime} \mathrm{W}$ at an altitude of $380 \mathrm{~m}$ a.s.l. Ablation was determined as the average of readings at ten stakes drilled within an area of about $100 \mathrm{~m}^{2}$. Two thermistor strings were also installed to measure temperature gradients in the top $3 \mathrm{~m}$ of the glacier surface. At the same time as the ablation measurements, meteorological data (air temperature, relative humidity and wind speed) were obtained once-hourly and recorded by data loggers at base camp and at the glacier station. Radiation conditions were studied by continuous logging of global radiation and all-wave (short- and longwave) incoming radiation at the base camp, while albedo was measured at the glacier station. Weather conditions were rather stable throughout the whole field period with nearly continuous sunshine, little cloud amount, nearly constant temperatures (daily means of $3-6^{\circ} \mathrm{C}$ ) and strong winds from the ice sheet (daily means of $3-8 \mathrm{~m} \mathrm{~s}^{-1}$ ). Cloud observations (amount and type) were made six times a day using World Meteorological Organization classification schemes. The interior of Kronprins Christian Land is obviously drier and has more sunshine than the coast in general, e.g. Station Nord 


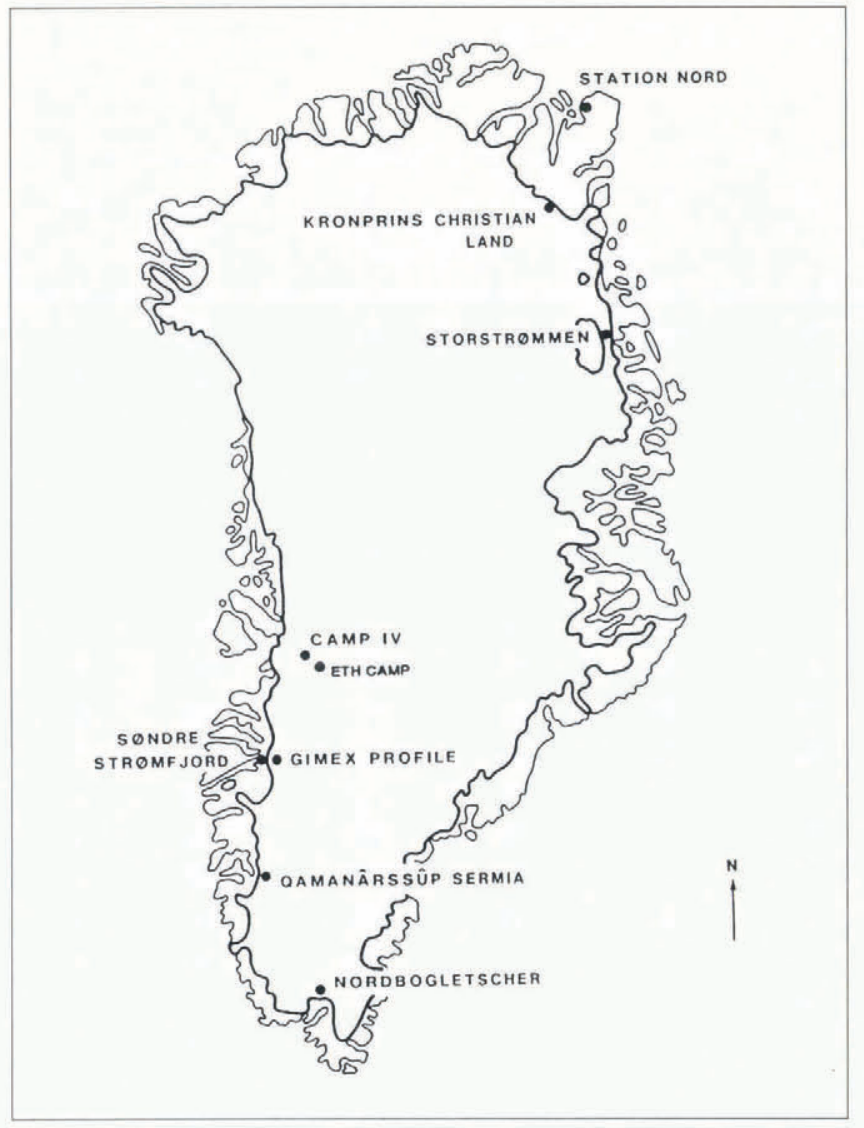

Fig. 1. Location of glaciological studies on the Greenland ice sheet referred to in the text.

is notorious for fog and late-lying snow. The fine weather conditions during the period of observation were probably not completely typical as there was a strong anticyclone over Greenland for most of the field period (Geb and Naujokat, 1993).

Ambach (1963) showed for the upper ablation area (Camp IV) that the energy gain at the surface in summer is caused mainly by the radiative fluxes as the sensibleand latent-heat fluxes almost cancel each other. At ETH Camp Ohmura and others, 1991, 1992; Fig. 1), which is located close to the mean equilibrium-line altitude (ELA), net radiation provides almost all of the ablation energy (Ohmura and others, in press). Radiation was also expected to be the main source of ablation energy at the present study site. In the lower ablation area of a glacier or an ice sheet, large variations of the surface reflectivity (albedo) can be expected. This is due mainly to different ice conditions, e.g. age, surface undulation, contamination, slope and orientation. These variations in albedo affect the energy balance and the ablation rate, and the relation between small-scale variations of ablation and albedo is treated as the main point of the present paper.

The smaller, less important energy-balance components, such as turbulent fluxes and conductive-heat flux in the ice, were evaluated by methods requiring only lightweight equipment. Morris (1989) suggested that accuracy in estimating energy-balance components should be commensurate with their relative importance in the overall energy balance. We extend this concept by replacing "accuracy" with "logistic cost". For example, the turbulent components were estimated from simple climatic data using profile-aerodynamic formulae (Ambach, 1986), thus saving the weight of heavy instruments. By analogy with preliminary geological surveys, such an approach may be termed a reconnaissance energybalance study and it is hoped that the present results legitimate the approach.

\section{ABLATION}

Previous experience has shown that ablation measurements involve considerable error and that ablation itself varies greatly even on a scale of metres (Olesen and Braithwaite, 1989), suggesting that many measurements are needed to obtain a representative value for a site.

The ten stakes were read daily close to $1900 \mathrm{~h}$ local time (about $1715 \mathrm{~h}$ solar time). As stakes are usually surrounded by an "ablation hollow" of $0.1-0.3 \mathrm{~m}$ diameter, stake readings were made by measuring from the top of each stake to a straight edge laid on the upstream side of the stake which defines an average level of the surrounding surface. Differences in successive daily readings are converted into ablation values assuming an ice density of $900 \mathrm{~kg} \mathrm{~m}^{-3}$. We find it convenient to treat ablation as a positive rather than negative quantity as recommended by Anon. (1969) to avoid the clumsiness of having to say that (negative) ablation decreases with increasing availability of energy.

The stakes were placed so that five were located in "dark" areas and five in "light" areas. These were sections of the ice surface which had "dark" and "light" color, respectively, based on visual inspection at the beginning of the field work. The difference between the two kinds of surface appears to be whether debris is spread evenly over the surface ("dark") or concentrated into a few deep cryconite holes surrounded by very white ice ("light").

Ablation variations from day-to-day and between stakes were analysed by the simple linear model of Lliboutry (1974):

$$
y_{j t}=\alpha_{j}+\beta_{t}+\epsilon_{j t},
$$

where $y_{j t}$ is the ablation at stake $j$ on day $t, \alpha_{j}$ is the mean ablation at stake $j, \beta_{t}$ is the ablation deviation which is the same for all stakes on day $t$, and $\epsilon_{j t}$ is the error in the model which is assumed to be random. Measurement errors contribute to the error term as long as they are random but if they are systematic, i.e. shared by all stakes, they contribute to the ablation deviation. According to Braithwaite and Olesen (1989), readings at the individual stakes should be approximately equally correlated with the ablation deviation $\beta_{j t}$. At ablation stake B, however, the correlation coefficient between the ablation deviation and data is only 0.36 while correlations for other stakes are in the range 0.83-0.95. Unfortunately, stake B was located on a steep slope which made it difficult to use the straight-edge method. Because of inconsistency with the other stakes, data from that stake are dropped from any further analysis. The ablation variations at the remaining nine stakes are shown in Table 1. The error in the linear model for the nine-stake, $20 \mathrm{~d}$ matrix is surprisingly low with a standard deviation 
Table 1. Daily ablation at nine stakes ( $A-\mathcal{J}$, excluding $B$ ) on the margin of the Greenland ice sheet, Kronprins Christian Land, July 1993. Units are $\mathrm{kg} \mathrm{m}^{-2} \mathrm{~d}^{-1}$

\begin{tabular}{|c|c|c|c|c|c|c|c|c|c|c|c|}
\hline $\begin{array}{c}\text { Date } \\
\text { July } 1993\end{array}$ & $A$ & $C$ & $D$ & $E$ & $F$ & $G$ & $H$ & $I$ & J & Mean & s.d. \\
\hline 8 & 36 & 40 & 31 & 31 & 31 & 36 & 23 & 31 & 31 & 32 & 5 \\
\hline 9 & 58 & 63 & 54 & 50 & 50 & 50 & 45 & 45 & 58 & 53 & 6 \\
\hline 10 & 58 & 58 & 40 & 45 & 45 & 54 & 45 & 45 & 45 & 48 & 7 \\
\hline 11 & 40 & 31 & 40 & 36 & 27 & 36 & 27 & 27 & 31 & 33 & 5 \\
\hline 12 & 45 & 54 & 27 & 27 & 27 & 31 & 27 & 23 & 36 & 33 & 10 \\
\hline 13 & 31 & 31 & 27 & 31 & 27 & 31 & 27 & 23 & 27 & 28 & 3 \\
\hline 14 & 58 & 40 & 50 & 45 & 31 & 50 & 40 & 40 & 45 & 44 & 8 \\
\hline 15 & 63 & 54 & 50 & 58 & 68 & 63 & 50 & 54 & 63 & 58 & 7 \\
\hline 16 & 58 & 58 & 54 & 40 & 40 & 45 & 36 & 40 & 45 & 46 & 8 \\
\hline 17 & 45 & 31 & 40 & 31 & 31 & 40 & 40 & 27 & 40 & 36 & 6 \\
\hline 18 & 45 & 45 & 45 & 45 & 31 & 45 & 36 & 36 & 50 & 42 & 6 \\
\hline 19 & 58 & 50 & 54 & 50 & 50 & 45 & 50 & 45 & 50 & 50 & 4 \\
\hline 20 & 58 & 58 & 54 & 50 & 54 & 50 & 45 & 50 & 54 & 53 & 4 \\
\hline 21 & 54 & 54 & 50 & 50 & 50 & 45 & 45 & 36 & 54 & 49 & 6 \\
\hline 22 & 45 & 40 & 45 & 36 & 40 & 36 & 40 & 36 & 45 & 40 & 4 \\
\hline 23 & 50 & 54 & 54 & 54 & 50 & 45 & 45 & 50 & 50 & 50 & 4 \\
\hline 24 & 36 & 36 & 31 & 27 & 31 & 31 & 31 & 23 & 36 & 31 & 4 \\
\hline 25 & 31 & 27 & 45 & 27 & 18 & 31 & 31 & 27 & 31 & 30 & 7 \\
\hline 26 & 23 & 31 & 18 & 31 & 18 & 27 & 27 & 18 & 31 & 25 & 6 \\
\hline 27 & 36 & 36 & 31 & 40 & 40 & 31 & 31 & 27 & 31 & 34 & 5 \\
\hline Mean & 46 & 45 & 42 & 40 & 38 & 41 & 37 & 35 & 43 & 41 & \\
\hline s.d. & 12 & 12 & 11 & 10 & 13 & 10 & 9 & 11 & 11 & 10 & \\
\hline
\end{tabular}

of only $\pm 5 \mathrm{~kg} \mathrm{~m}^{-2} \mathrm{~d}^{-1}$ which is certainly small compared with the range \pm 13 to $\pm 19 \mathrm{~kg} \mathrm{~m}^{-2} \mathrm{~d}^{-1}$ quoted by Braithwaite (1985, p. 21-22).

The hypothesis that the four "dark" stakes (A, C, D and $G$ ) have the same mean ablation as the five "light" stakes $(\mathrm{E}, \mathrm{F}, \mathrm{H}, \mathrm{I}$ and $\mathrm{J})$ is tested with the Student $t$ test (Kreyszig, 1968, p. 219). The mean and standard deviations for the two data sets are $44 \pm 9 \mathrm{~kg} \mathrm{~m}^{-2} \mathrm{~d}^{-1}$ and $39 \pm 10 \mathrm{~kg} \mathrm{~m}^{-2} \mathrm{~d}^{-1}$, respectively. The mean values are different (at $5 \%$ significance level) and it can be concluded that "dark" stakes have significantly greater ablation than "light" stakes. The time series of ablation energy for "light" and "dark" stakes are presented in Figure 2.

The glacier surface consisted almost always of a 20 $30 \mathrm{~mm}$ thick "weathering crust" (Müller and Keeler, 1969) with a relatively low density. The effect of this crust on the evaluation of ablation deserves discussion. The ablation in a period is the loss of material in the surface layer of thickness $h$ relative to a stake fixed in the ice. The total surface-layer thickness $h$ consists of a layer of ice of thickness $h_{\mathrm{i}}$ and a layer of crust of thickness $h_{\mathrm{c}}$. The ablation is given by:

$$
y=\Delta h \rho_{\mathrm{i}}+\Delta h_{\mathrm{c}}\left(\rho_{\mathrm{c}}-\rho_{\mathrm{i}}\right),
$$

where $\Delta h$ is the change in surface-layer thickness, $\Delta h_{\mathrm{c}}$ is the change in crust thickness, and $\rho_{\mathrm{c}}$ and $\rho_{\mathrm{i}}$ are the densities of crust and ice, respectively. As the depth of crust is not observed and its density is unknown, the ablation is evaluated using only the first term with an ice density of $900 \mathrm{~kg} \mathrm{~m}^{-3}$ which refers to slightly bubbly glacier ice. Some attempts were made in 1986 at Qamanârssûp sermia to measure the density of crust with a miniature corer (unpublished data from R.J.

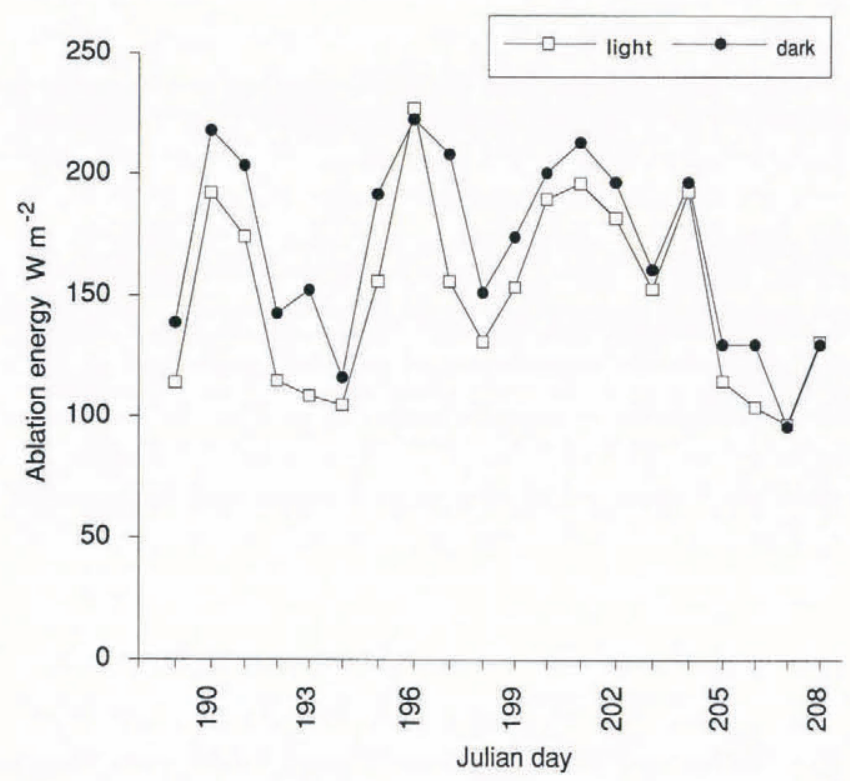

Fig. 2. Ablation energy for "light" and "dark" stakes, 8 27 July 1993 (Julian days 189-208), at Kronprins Christian Land. Unit is $\mathrm{Wm}^{-2}$. 
Braithwaite). Although these data cannot be very accurate, a crust density of $500-700 \mathrm{~kg} \mathrm{~m}^{-3}$ was indicated. Over the whole $20 \mathrm{~d}$ period of the field experiment with an average $\Delta h$ of $0.9 \mathrm{~m}$, the second term, involving change in crust thickness, is entirely negligible. For the daily ablation readings, however, the second term could be a significant source of error although the weathering crust never completely disappeared in the present experiment as observed by Müller and Keeler (1969) in their data sets. It should be noted that an error of this kind is not detected by the Lliboutry model because the error is more-or-less common to all stakes.

\section{RADIATIVE FLUXES}

Due to the importance of radiative fluxes in the energy balance, priority was given to accurate radiation measurements. At the base camp, global radiation and allwave incoming radiation were measured directly with a Swissteco SS-25 pyranometer and a Swissteco ST-25 pyrradiometer, respectively. The longwave incoming radiation was then calculated as the difference between the all-wave incoming radiation and the global radiation, and compensated for the emission loss of the instrument $\left(\sigma T_{\mathrm{i}}^{4}\right)$, where $\sigma$ is the Stefan-Boltzmann constant $\left(=5.67 \times 10^{-8} \mathrm{~W} \mathrm{~m}^{-2} \mathrm{~K}^{-4}\right)$ and $T_{\mathrm{i}}$ the temperature of the pyrradiometer in kelvin. The cosine error of the upfacing pyranometers was corrected for zenith angle $>70^{\circ}$ using a polynomial function, whereby only the part of direct solar radiation was taken into account. Based on measurements made under similar meteorological cond-itions at ETH Camp in June 1990, it was assumed that $70 \%$ of global radiation is caused by direct solar radiation (Konzelmann, 1994). Due to a possible underestimation of the all-wave incoming radiation due to thermal convection as proposed by Ohmura and Gilgen (1993), the longwave incoming radiation was corrected accordingly. Shortwave radiative fluxes at the glacier station were measured with a Swissteco SW-2 two-component pyranometer (albedometer). The instrument was mounted on a tripod at a height of about $1 \mathrm{~m}$ and was relocated every second day to sample as many types of surface as possible. In general, global radiation at the glacier station and at base camp agreed closely. However, to avoid possible systematic errors due to any tilt of the radiometer at the glacier station, global radiation measured at base camp was used to calculate albedo together with shortwave reflected radiation at the glacier station. Assuming melting conditions all day at the glacier station, longwave outgoing radiation was set at $316 \mathrm{~W} \mathrm{~m}^{-2}$ according to the Stefan-Boltzmann law.

The response time of the radiometers is about $5 \mathrm{~s}$ and the signals of the instruments were continuously recorded every 15 s. Every $30 \mathrm{~min}$ the average was computed and stored. The operation of the instruments and data loggers was checked several times a day. The uncertainty in the longwave incoming radiation was set at $\pm 10 \mathrm{Wm}^{-2}$ according to the correction method mentioned above and an instrument intercomparison performed by DeLuisi and others (1993).

\section{TURBULENT FLUXES}

The sensible-heat flux (SHF) is estimated by the method of Ambach (1986) from measured wind speed and temperature:

$$
\mathrm{SHF}=K_{\mathrm{S}} P u_{2} T_{2},
$$

where $K_{\mathrm{S}}$ is the exchange coefficient for turbulent-heat flux, $P$ is the atmospheric pressure, $u_{2}$ is the wind speed at $2 \mathrm{~m}$ above the glacier surface and $T_{2}$ is the air temperature at $2 \mathrm{~m}$ above the glacier surface. The glacier surface is assumed to be at the melting point. For a Prandtl-type neutral boundary layer with logarithmic profiles for wind speed, temperature and vapour pressure, the exchange coefficient is given by:

$$
K_{\mathrm{S}}=c_{\mathrm{p}} \mathrm{k}^{2} \rho_{0} /\left[b_{0} \ln \left(z / z_{0 \mathrm{w}}\right) \ln \left(z / z_{0 \mathrm{~T}}\right],\right.
$$

where $c_{\mathrm{p}}$ is the specific heat of air with constant pressure $\left(1005 \mathrm{~J} \mathrm{~kg}^{-1} \mathrm{~K}^{-1}\right), \mathrm{k}$ is von Karman's constant $(0.41), \rho_{0}$ is the density of air in the standard condition $\left(1.29 \mathrm{~kg} \mathrm{~m}^{-3}\right)$, $b_{0}$ is the standard atmospheric pressure $\left(1.013 \times 10^{5} \mathrm{~Pa}\right)$, $z$ is the instrument height $(2 \mathrm{~m})$ and $z_{0 \mathrm{w}}$ and $z_{0 \mathrm{~T}}$ are the roughness lengths for logarithmic profiles of wind and temperature, respectively.

The latent-heat flux (LHF) is similarly estimated from measured data for wind speed and vapour pressure:

$$
\mathrm{LHF}=K_{\mathrm{L}} u_{2} \Delta e_{2},
$$

where $K_{\mathrm{L}}$ is the exchange coefficient for latent-heat flux and $\Delta e_{2}$ is the difference between vapour pressure at $2 \mathrm{~m}$ above the glacier surface and that at the melting glacier surface. For the same assumptions as before, the exchange coefficient is given by:

$$
K_{\mathrm{L}}=L \mathrm{k}^{2} \rho_{0} 0.623 /\left[b_{0} \ln \left(z / z_{0 \mathrm{w}}\right) \ln \left(z / z_{0 \mathrm{e}}\right)\right],
$$

where $L$ is the latent heat of evaporation or sublimation as appropriate $\left((2.514\right.$ or 2.849$\left.) \times 10^{6} \mathrm{~J} \mathrm{~kg}^{-1}\right)$ and $z_{0 \mathrm{e}}$ is the roughness length for the logarithmic profile of water vapour.

Following Ambach (1986), the roughness length for wind over an ice surface is assumed to be $2.0 \times 10^{-3} \mathrm{~m}$ while the roughness lengths for temperature and water vapour are both assumed to be $6.0 \times 10^{-6} \mathrm{~m}$. As formulated by Ambach (1986), the exchange coefficients $K_{\mathrm{S}}$ and $K_{\mathrm{L}}$ are valid for a neutral boundary layer while the air just over a glacier surface may be rather stable.

The turbulent-heat fluxes were calculated every hour according to Equations (4) and (6) using the air temperature, relative humidity and wind speed measured at $2 \mathrm{~m}$. Some radiation heating of the temperature/humidity screen was noted whereby temperatures sud-denly rose when wind speeds were low, and the data were corrected by hand. Hourly values of the calculated turbulent fluxes and half-hourly values of the radiative fluxes were then summed up to daily values ending at $1900 \mathrm{~h}$ local time, so they could be compared directly with ablation measurements made at that time. 


\section{ICE TEMPERATURES AND CONDUCTIVE-HEAT FLUX IN THE ICE}

It was expected that the conductive-heat flux in the ice would be a significant energy sink in contrast to the icesheet margin in West Greenland where it was assumed by Braithwaite and Olesen (1990) to be negligibly small. Englacial temperatures were therefore measured every day to calculate the conductive-heat flux in the ice. The measurements were made at two strings with thermistors which were drilled at $0.5 \mathrm{~m}$ intervals down to a maximum of $3 \mathrm{~m}$ depth.

Measured temperatures were even lower than expected with the $0^{\circ} \mathrm{C}$ isotherm only $0.2-0.3 \mathrm{~m}$ below the surface (even with the possible help of radiation warming of the thermistor cables). This probably accounts for the rather difficult drilling conditions encountered when placing the stakes, i.e. a wet drill barrel penetrating very cold ice and frequently jamming. During the period of measurements, the ice temperatures at the various depths rose by $0.2-0.3 \mathrm{~K} \mathrm{~d}^{-1}$.

The rate of change of ice temperature with time is $\partial T / \partial t$ given by:

$$
\partial T / \partial t=-\left(1 / \rho_{\mathrm{i}} c\right) \mathrm{d} H(z) / \mathrm{d} z,
$$

where $\rho_{\mathrm{i}}$ is density of ice $\left(900 \mathrm{~kg} \mathrm{~m}^{-3}\right), c$ is specific heat of ice $\left(2009 \mathrm{~J} \mathrm{~kg}^{-1} \mathrm{~K}^{-1}\right), H(z)$ is the englacial-heat flux and $z$ is the depth below the surface. Assuming that $\partial T / \partial t$ equals a constant $C$ during the period of measurements, then $H(z)$ is a linear function of depth:

$$
H(z)=H_{0}-C \rho_{\mathrm{i}} c z,
$$

where $H_{0}$ is the heat flux through the glacier surface at $z=0 \mathrm{~m}$. Equation (8) suggests that $H_{0}$ can be calculated as the intercept in a regression equation of heat flux versus depth where the heat flux $H(z)$ is calculated from englacial-temperature data according to the equation

$$
H(z)=-K \partial T / \partial z
$$

where $K$ is the thermal conductivity of ice, $2.1 \mathrm{~W} \mathrm{~m}^{-1} \mathrm{~K}^{-1}$ according to Paterson (1981, p. 186). The heat fluxes for each day are strongly correlated with depth with generally similar equations and, assuming that any differences are due to statistical fluctuations, the mean heat flux $H_{0}$ for the whole period was calculated by combining all the available data into a single regression equation (Fig. 3). The intercept is $17.6 \mathrm{~W} \mathrm{~m}^{-2}$ and the slope of the regression line corresponds to a constant temperature change of $0.21 \mathrm{~K} \mathrm{~d}^{-1}$ during the field period. Extrapolation of the regression line (Fig. 3) to greater depth suggests that the heat flux becomes zero at about $4 \mathrm{~m}$ depth but it is more likely that the approach to zero flux is asymptotic at greater depths than $4 \mathrm{~m}$.

\section{ENERGY BALANCE}

The energy used for ablation ABL is given by:

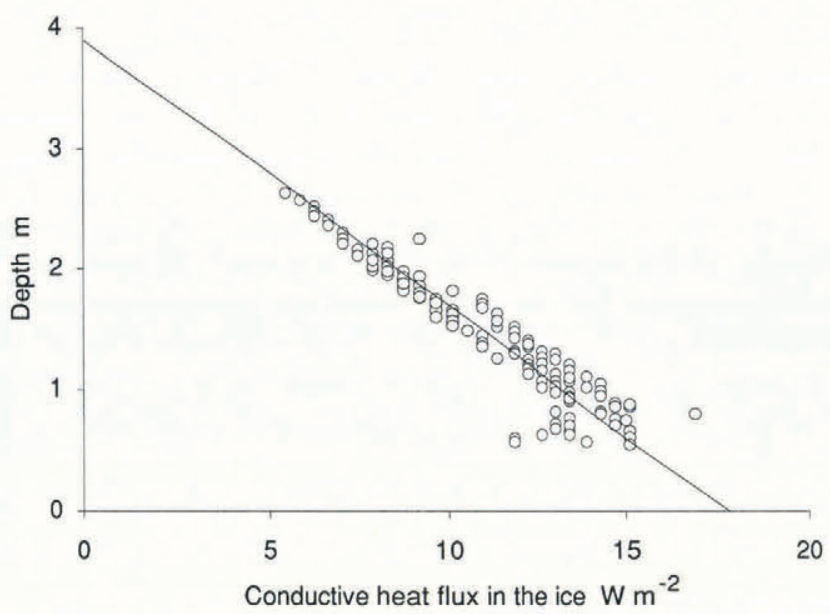

Fig. 3. Calculated conductive heat flux in the ice versus depth below the glacier surface, 827 July 1993.

$$
\mathrm{ABL}+\mathrm{CHF}=\mathrm{SWR}+\mathrm{LWR}+\mathrm{SHF}+\mathrm{LHF}+\mathrm{ERR},
$$

where $\mathrm{ABL}$ is calculated from measured ablation using the latent heat of fusion $\left(3.34 \times 10^{5} \mathrm{~J} \mathrm{~kg}^{-1}\right)$, CHF is conductive-heat flux in the ice, SWR is shortwave net radiation, LWR is longwave net radiation, SHF is sensible-heat flux, LHF is latent-heat flux, and ERR is the total error due to measurement errors, simplifying assumptions and disregarded terms in the energy-balance equation. Defined as above, ERR can be regarded as an unknown, extra source of energy which is estimated from the residual of the other terms in Equation (10). The magnitude of ERR is a useful check on the accuracy of the other terms. For calculation of SWR an albedo of 0.48 was used. The condutive-heat flux in the ice was taken as $17.6 \mathrm{~W} \mathrm{~m}^{-2}$. The time series of all components of the energy balance is presented in Figure 4.

The calculated energy balance for the $20 \mathrm{~d}$ is shown in Table 2 and summarised in Table 3 . As discussed below, the main error is probably due to the turbulent fluxes so that they probably constitute more than the $26 \%$ of ablation energy shown in the table.

\section{ERROR IN THE GALGULATED ENERGY BALANCE}

On average, the error term ERR represents nearly $11 \%$ of the total energy balance. In view of the uncertainty of the various assumptions, it is good that the mean error is not even larger. For example, Braithwaite and Olesen (1990) found errors of -40 to $+29 \%$ of monthly ablation at Nordbogletscher and Qamanârssûp sermia. In terms of variance, the error corresponds to about one-third of the ablation variance. There is therefore a substantial source of both systematic and random error in the energybalance calculation.

The error ERR has almost no correlation with the radiation terms SWR and LWR. On the other hand, the error has moderate correlation with the turbulent fluxes, i.e. $r=+0.63$ for SHF and $r=-0.53$ for LHF, which 


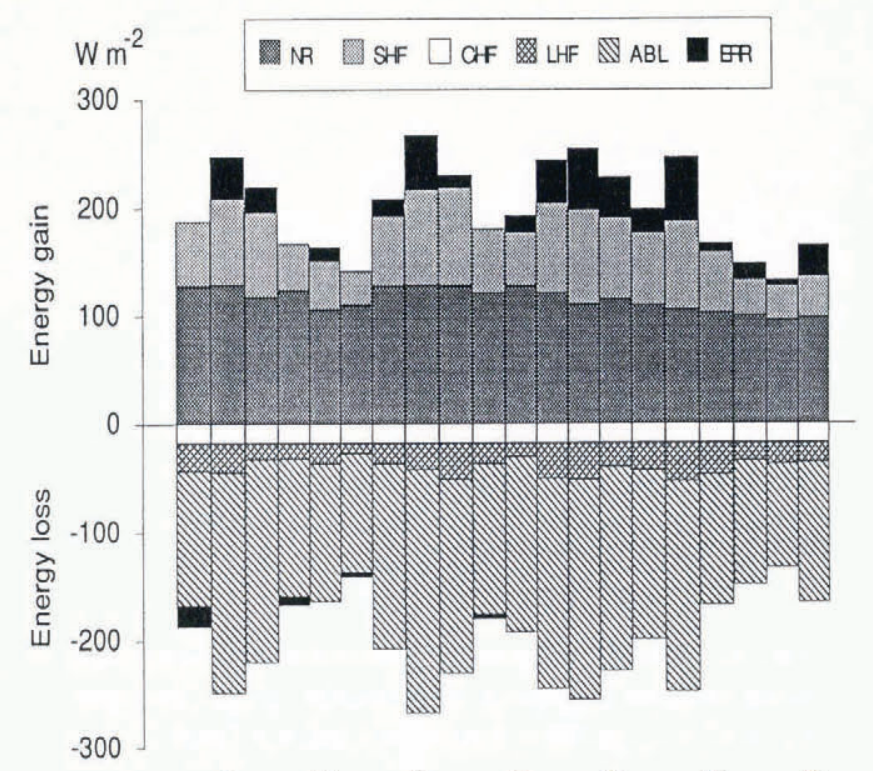

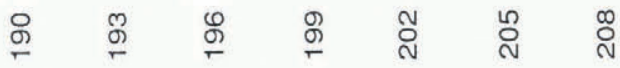

Fig. 4. Energy balance 8-27 July 1993 (Julian days 189208) at Kronprins Christian Land with net radiation $(\mathcal{N R})$, sensible-heat flux (SHF), latent-heat flux $(\mathrm{LHF})$, conductive-heat flux in the ice $(\mathrm{CHF})$, ablation energy (ABL) and error (ERR). ABL corresponds to stake measurements. ERR appears either on the top or on the bottom depending on whether there is a surplus or deficit of energy. Unit is $\mathrm{Wm}^{-2}$. suggests that they may be the main sources of systematic error in the calculated energy balance. For example, if both SHF and LHF are multiplied by a factor of 1.5 before calculating the energy balance, the mean error is essentially reduced to zero (the error standard deviation is little changed). In order to assess the plausibility of a $50 \%$ error in the turbulent fluxes it is necessary to examine in more detail how they are calculated, i.e. with regard to stability and to the assumed surface roughness.

The exchange coefficient for sensible-heat flux (Ambach, 1986) given by Equation (4) does not take account of the stability of the boundary layer over the melting glacier. Price and Dunne (1976) propose stability corrections in terms of the bulk Richardson number, and application of this reduces the sensible-heat flux in the present study by $5-18 \%$, thus increasing the error in the calculated energy balance rather than reducing it.

The Ambach (1986) formulation uses different roughness lengths for wind, temperature and water vapour (over ice) while Price and Dunne (1976) and Moore (1983) assume the same roughness lengths (over snow). Putting $z_{0 \mathrm{w}}=z_{0 \mathrm{~T}}=z_{0 \mathrm{e}}=10^{-3} \mathrm{~m}$ in Equations (4) and (6) would exactly account for the mean error in the calculated energy balance. Such a roughness length falls well within the wide range of values quoted in the literature for ice, e.g. by Grainger and Lister (1966), Streten and Wendler (1968), Wendler and Weller (1974), Poggi (1977) and Hay and Fitzharris (1988), although Morris (1989) suggests that some of the larger roughness

Table 2. Daily energy balance on the margin of the Greenland ice sheet, Kronprins Christian Land, July 1993. Units are W $\mathrm{m}^{-2}$

\begin{tabular}{|c|c|c|c|c|c|c|c|c|c|c|c|c|c|}
\hline $\begin{array}{c}\text { Date } \\
\text { July } 1993\end{array}$ & $S W R$ & + & $L W R$ & + & SHF & + & $L H F$ & + & $E R R$ & $=$ & $A B L$ & + & $\mathrm{CHF}$ \\
\hline 8 & 186.0 & & -58.0 & & 59.9 & & -25.4 & & -20.1 & & 124.9 & & 17.6 \\
\hline 9 & 182.9 & & -54.0 & & 79.7 & & -26.6 & & 39.4 & & 203.8 & & 17.6 \\
\hline 10 & 168.9 & & -51.0 & & 78.4 & & -14.6 & & 23.3 & & 187.4 & & 17.6 \\
\hline 11 & 178.8 & & -55.0 & & 43.8 & & -14.0 & & -8.9 & & 127.1 & & 17.6 \\
\hline 12 & 149.2 & & -43.0 & & 45.6 & & -18.5 & & 12.3 & & 128.0 & & 17.6 \\
\hline 13 & 145.6 & & -35.0 & & 31.2 & & 9.1 & & -5.2 & & 109.9 & & 17.6 \\
\hline 14 & 175.7 & & -48.0 & & 65.1 & & -18.4 & & 15.1 & & 171.9 & & 17.6 \\
\hline 15 & 174.6 & & -46.0 & & 88.2 & & -23.9 & & 50.0 & & 225.3 & & 17.6 \\
\hline 16 & 174.1 & & -46.0 & & 90.5 & & -33.3 & & 11.5 & & 179.2 & & 17.6 \\
\hline 17 & 159.1 & & -38.0 & & 59.5 & & -18.6 & & -4.4 & & 140.0 & & 17.6 \\
\hline 18 & 168.9 & & -41.0 & & 49.8 & & -12.4 & & 15.1 & & 162.8 & & 17.6 \\
\hline 19 & 170.5 & & -49.0 & & 82.7 & & -31.9 & & 40.0 & & 194.7 & & 17.6 \\
\hline 20 & 162.7 & & -52.0 & & 87.5 & & -33.2 & & 56.4 & & 203.8 & & 17.6 \\
\hline 21 & 159.6 & & -44.0 & & 75.6 & & -21.8 & & 36.9 & & 188.7 & & 17.6 \\
\hline 22 & 159.6 & & -50.0 & & 67.5 & & -25.0 & & 21.9 & & 156.4 & & 17.6 \\
\hline 23 & 156.5 & & -51.0 & & 82.2 & & -34.8 & & 59.4 & & 194.7 & & 17.6 \\
\hline 24 & 158.1 & & -56.0 & & 57.3 & & -28.6 & & 8.3 & & 121.5 & & 17.6 \\
\hline 25 & 159.6 & & -60.0 & & 33.8 & & -15.9 & & 15.6 & & 115.5 & & 17.6 \\
\hline 26 & 158.1 & & -63.0 & & 33.1 & & -19.2 & & 5.1 & & 96.5 & & 17.6 \\
\hline 27 & 155.5 & & -58.0 & & 38.8 & & -17.5 & & 29.3 & & 130.5 & & 17.6 \\
\hline Mean & 165.2 & & -49.9 & & 62.5 & & -22.1 & & 20.1 & & 158.2 & & 17.6 \\
\hline s.d. & 11.0 & & 7.4 & & 20.1 & & 7.6 & & 22.0 & & 37.8 & & 0.0 \\
\hline
\end{tabular}


values may be caused by slope errors. It appears, therefore, that the calculation of the energy balance is extremely sensitive to the assumptions about surface roughness in agreement with Munro (1989). This is an important point for future attempts to couple ice-sheet models to general circulation models (GCMs).

\section{EFFECT OF ALBEDO ON ABLATION}

Measurements of albedo are normally made at one point and therefore depend strongly on the local surface conditions. For an area of $50 \mathrm{~m} \times 100 \mathrm{~m}$ in the upper ablation zone (Camp IV), Ambach (1963) gives a variation of the albedo from 0.34 to 0.58 for a particular day. Preliminary results from an altitudinal profile of albedo on bare ice close to the present study site show albedo variations of between 0.30 and 0.62 (personal communication from $\mathrm{H}$. Oerter).

On a total of $16 \mathrm{~d}$, albedo was measured at different places inside the area of ablation measurements. Parts with "dark" surface ( $8 \mathrm{~d})$ and "light" surface $(8 \mathrm{~d})$ were selected subjectively. For the "dark" surface a mean albedo of 0.43 was found and the "light" surface showed a mean value of 0.53 , while the mean albedo of all sites was 0.48 . The albedo difference between "light" and "dark" surfaces is here 0.10 . For a daily mean global radiation of $320 \mathrm{~W} \mathrm{~m}^{-2}$, this gives a difference in calculated melt of $8.3 \mathrm{~kg} \mathrm{~m}^{-2} \mathrm{~d}^{-1}$ which is about $20 \%$ of the mean ablation over the whole data set (Table 1). The difference in mean ablation between the four "dark" and the five "light" stakes is $5 \mathrm{~kg} \mathrm{~m}^{-2} \mathrm{~d}^{-1}$ while the greatest inter-stake difference is $11 \mathrm{~kg} \mathrm{~m}^{2} \mathrm{~d}^{-1}$ between stakes A and I (Table 1).

The above discussion refers to separate ablation and albedo variations within an area, and it would be interesting to extend the discussion to the relation between ablation and albedo for individual stakes. However, it is impossible to measure albedo exactly at a stake because the stake and the albedometer interfere with each other, and a more subjective procedure for estimating albedo at each stake is used. In this method, the surface conditions under the albedometer were compared on each day to the situations at nearby stakes, and the measured albedo value was assigned to one or more stakes that appeared to have a similar surface. The albedo for each stake was then determined as the average of the assigned albedo values. The estimated albedos of the four "dark" stakes (A, C, D and G) agree closely but there is quite a large range for the five "light" stakes. Average albedos for the groups are higher than previously stated, but this simply reflects the different sampling. The relation between mean daily ablation and the estimated albedo for the individual stakes is illustrated by Figure 5 . The correlation shows a value of $r=-0.82$, which again suggests that albedo is a main factor in ablation variations within a small area.

The above indicates that a point measurement of albedo is not sufficient for accurate energy-balance calculations in ablation areas. Therefore, an albedo value for a larger area should be determined, either by measurements from high towers (Langleben, 1968) or by enough point measurements at ground level to sample small-scale albedo variations as attempted here.

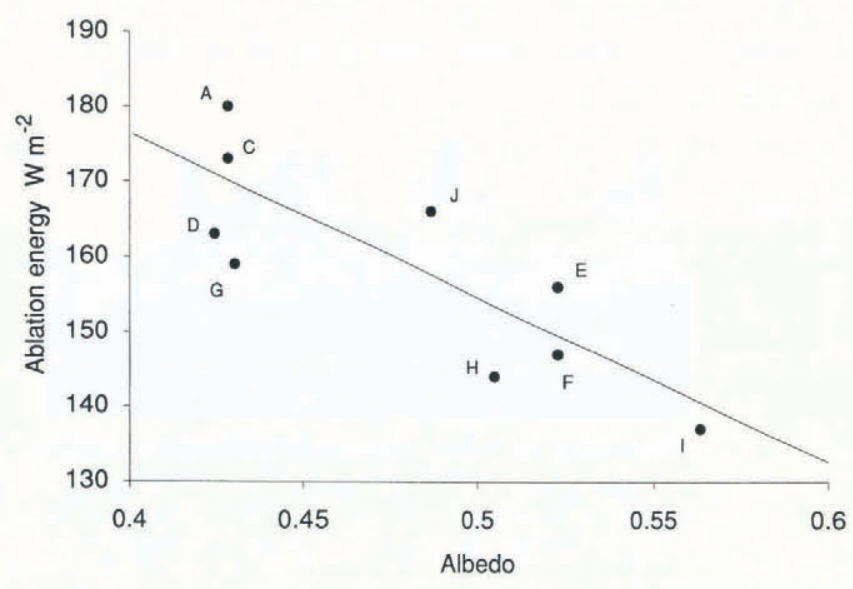

Fig. 5. Ablation energy in $\mathrm{Wm}^{-2}$ as a function of albedo based on mean daily values on the margin of the Greenland ice sheet in July 1993, Kronprins Christian Land.

\section{COMPARISON WITH WEST GREENLAND}

In West Greenland, energy-balance studies were carried out by Braithwaite and Olesen (1990) at Nordbogletscher (NBG) and Qamanârssûp sermia (QAM), and by Van de Wal and Oerlemans (1994) near Søndre Strømfjord in environments similar to those found at the present study site (KCL). At all of these stations the net radiation was measured at one point and no albedo variation was taken into account. Ambach (1963) performed a more sophisticated energy-balance study at Camp IV, but the station was located in the upper ablation area, and the albedo variations and their effect on ablation were unfortunately not analysed in detail. The energy balance from different experiments is summarized in Table 3. Net radiation is the main source of ablation energy at all locations. Turbulent fluxes are an important energy source in the ablation zone compared to the situation close to the ELA (Ambach, 1963; Ohmura and others, in press), corresponding to an ablation rate of about 10

Table 3. Energy balance in fuly 1993 in Kronprins Christian Land (KCL) compared with July values at Qamanârssûp sermia (QAM) for 1980 86 and Nordbogletscher (NBG) for 1979-83 from Braithwaite and Olesen (1990). Signs correspond to the definition given in Equation (10). Small letter (a) indicates a value assumed to be $0 \mathrm{Wm}^{2}$

\section{KCL QAM NBG}

$\begin{array}{lcrrr}\text { Elevation } & \mathrm{m} & 380 & 790 & 890 \\ \text { Days } & & 20 & 185 & 155 \\ \text { Net radiation } & \mathrm{W} \mathrm{m}^{-2} & 115 & 123 & 89 \\ \text { Turbulent fluxes } & \mathrm{W} \mathrm{m}^{-2} & 40 & 79 & 44 \\ \text { Heat conduction } & \mathrm{W} \mathrm{m}^{-2} & 18 & \mathrm{a} & \mathrm{a} \\ \text { Error } & \mathrm{W} \mathrm{m}^{-2} & 20 & -4 & 2 \\ \text { Melting energy } & \mathrm{W} \mathrm{m}^{-2} & 157 & 198 & 135\end{array}$


$20 \mathrm{~kg} \mathrm{~m}^{-2} \mathrm{~d}^{-1}$. In contrast to West Greenland where heat conduction into the ice is assumed to be small, it is an important heat sink in the present study. The possible ablation is reduced by about $4.5 \mathrm{~kg} \mathrm{~m}^{-2} \mathrm{~d}^{-1}$.

Ablation rates and degree-day factors for KCL, QAM and NBG are summarized in Table 4. Despite the low elevation of the station compared with the two West Greenland sites, the ablation rate is quite low. This is partly due to lower air temperature, but that is offset by a higher degree-day factor. At KCL a value of $9.8 \mathrm{~mm}$ $\mathrm{d}^{-1}{ }^{-1} \mathrm{C}^{-1}$ was found compared with $7.2-8.1 \mathrm{~mm} \mathrm{~d}^{-1}{ }^{\circ} \mathrm{C}^{-1}$ at the West Greenland sites (Braithwaite, 1992), which may be the result of higher wind speeds. Boggild and others (1994) also got a higher degree-day factor $\left(9.6 \mathrm{~mm} \mathrm{~d}^{-1}\right.$ ${ }^{\circ} \mathrm{C}^{-1}$ ) at Storstrømmen in northeast Greenland (Fig. 1).

Table 4. Ablation rate and degree-day factor in Fuly 1993 in Kronprins Christian Land (KCL) compared with July values at Qamanârssûp sermia (QAM) for 198086 and Nordbogletscher (NBG) for 197983 from Braithwaite (1992)

\section{KCL $Q A M \quad N B G$}

\begin{tabular}{lcrrr} 
Elevation & $\mathrm{m}$ & 380 & 790 & 890 \\
Days & & 20 & 185 & 155 \\
Ablation rate & $\mathrm{mm} \mathrm{d}^{-1}$ & 40 & 53 & 35 \\
$\begin{array}{l}\text { Air temperature } \\
\text { Degree-day }\end{array}{ }^{\circ} \mathrm{C}$ & 4.2 & 6.3 & 4.6 \\
$\quad \mathrm{~mm} \mathrm{~d}^{-1}{ }^{-} \mathrm{C}^{-1}$ & 9.8 & 8.1 & 7.2 \\
$\begin{array}{l}\text { factor } \\
\text { Wind speed }\end{array}$ & $\mathrm{m} \mathrm{s}^{-1}$ & 6.2 & 4.8 & 3.2 \\
& & & & \\
\hline
\end{tabular}

\section{CONCLUSIONS}

Net radiation is the major source of ablation energy at the margin of the Greenland ice sheet in Kronprins Christian Land as in other parts of Greenland. Albedo varies greatly within a small area and, because of the high income of global radiation, causes relatively large differences in ablation at stakes close to each other. Small-scale albedo variations must therefore be carefully sampled to obtain representative albedo values for largescale energy-balance calculation.

The calculated energy balance in the present study also has a substantial error which may be caused by underestimation of the turbulent fluxes using the aerodynamic formulae of Ambach (1986). The reason is probably that the glacier surface is rougher than assumed. The conductive-heat flux in the ice is a substantial heat sink and reduces the energy available for ablation. The average ablation rate in Kronprins Christian Land in July is low compared with values in West Greenland, reflecting lower temperature although this is partly offset by a higher degree-day factor due to high wind speed. The degree-day factor is significantly higher in north Greenland than the ones found in West Greenland.

\section{ACKNOWLEDGEMENTS}

This paper is published by permission of The Geological Survey of Greenland (GGU). K. Schroff (Department of Geography, Swiss Federal Institute of Technology) and O. Olesen (GGU) prepared instruments. Logistic support was supplied by GGU's camp at Centrum Sø, Kronprins Christian Land, led by GGU Statsgeolog N. Henriksen. The research is supported by the European Community under contract number EV5V-CT91-0051 which is coordinated by the Climate Research Unit, University of East Anglia. The first draft of this paper was prepared in November 1993 when R.J. Braithwaite was a guest of Professor A. Ohmura, Department of Geography, Swiss Federal Institute of Technology (grant No. 0-04-509-93). Professor Ohmura also made useful comments on the manuscript.

\section{REFERENCES}

Ambach, W. 1963. Untersuchungen zum Energieumsatz in der Ablationszone des grönländischen Inlandeises (Camp IV-EGIG, $69^{\circ} 40^{\prime} 05^{\prime \prime}$ N, $49^{\circ} 37^{\prime} 58^{\prime \prime}$ W). Medd. Gronl., $174(4)$.

Ambach, W. 1986. Nomographs for the determination of meltwater from snow- and ice surfaces. Berichte des NaturwissenschaflichMedizinischen Vereins in Innsbruck, 73, 7-15.

Anon. 1969. Mass-balance terms. F. Glaciol., 8 (52), $3-7$.

Boggild, C.E., N. Reeh and H. Oerter. 1994. Modelling ablation and mass-balance sensitivity to climate change of Storstrommen, northeast Greenland. Global and Planetary Change, 9, 7990.

Braithwaite, R.J. 1985. Glaciological investigations at Qamanârssûp sermia, West Greenland, 1983-1984. Gronlands Geologiske Undersogelse. Gletscher-Hydrologiske Meddelelser 85/3.

Braithwaite, R.J. 1992. Degree-day factor, energy balance, and the increased melting of the Greenland ice sheet under a warmer climate. Gronlands Geologiske Undersogelse. Rapport 155, 7983.

Braithwaite, R.J. and O. B. Olesen. 1989. Calculation of glacier ablation from air temperature, West Greenland. In Oerlemans, J., ed. Glacier fluctuations and climatic change. Dordrecht, Kluwer Academic Publishers, $219-233$.

Braithwaite, R.J. and O.B. Olesen. 1990. A simple energy-balance model to calculate ice ablation at the margin of the Greenland ice sheet. 7. Glaciol., 36(123), $222-228$.

DeLuisi, J., K. Dehne, R. Vogt, T. Konzelmann and A. Ohmura. 1993. First results of the baseline surface radiation network (BSRN) broadband infrared radiometer intercomparison at FIRE II. In Keevallik, S. and O. Kärner, eds. Current problems in atmospheric radiation. International Radiation Symposium, Tallinn 1992. Hampton, VA, A. Deepak Publishing, $559-564$.

Geb, M. and B. Naujokat. 1993. Nordhemisphärischer Klimabericht zum Juni/Juli/August 1993. Beilage zur Berliner Wellerkarle. Berlin, Freie Universität Berlin. Institut für Meteorologie.

Grainger, M.E. and H. Lister. 1966. Wind speed, stability and eddy viscosity over melting ice surfaces. 7. Glaciol., 6(43), 101-127.

Hay, J.E. and B.B. Fitzharris. 1988. A comparison of the energybalance and bulk-aerodynamic approaches for estimating glacier melt. f. Glaciol., 34(117), 145-153.

Konzelmann, T. 1994. Radiation conditions on the Greenland ice sheet. Zürcher Geographische Schriften 56.

Kreyszig, E. 1968. Statistische Methoden und ihre Amwendungen. Göttingen, Vandenhoeck and Ruprecht.

Langleben, M. P. 1968. Albedo measurements of an Arctic ice cover from high towers. 7. Glaciol., 7 (50), 289297.

Lliboutry, L. 1974. Multivariate statistical analysis of glacier annual balances. f. Glaciol., 13 (69), 371-392.

Moore, R. D. 1983. On the use of bulk aerodynamic formulae over melting snow. Nord. Hydrol., 14(4), $193-206$.

Morris, E. M. 1989. Turbulent transfer over snow and ice. J. Hydrol., 105, 205223.

Müller, F. and C. M. Keeler. 1969. Errors in short-term ablation measurements on melting ice surfaces. J. Glaciol., 8(52), 91105.

Munro, D.S. 1989. Surface roughness and bulk heat transfer on a glacier: comparison with eddy correlation. f. Glaciol., 35 (121), 343-348. 
Ohmura, A. and H. Gilgen. 1993. Re-evaluation of the global energy balance. Geophys. Monogr., Am. Geophys. Union 75, 93-110.

Ohmura, A. and 8 others. 1991. Energy and mass balance during the melt season at the equilibrium line altitude, Paakitsoq, Greenland ice sheet. ETH Greenland Expedition. Progress Report No. 1. Zürich, Swiss Federal Institute of Technology,

Ohmura, A. and 10 others. 1992. Energy and mass balance during the melt season at the equilibrium line altitude, Paakitsoq, Greenland ice sheet. ETH Greenland Expedition. Progress Report No. 2. Zürich, Swiss Federal Institute of Technology.

Ohmura, A., T. Konzelmann, J. Forrer, A. Abe-Ouchi and H. Toritani. In press. Energy balance for the Greenland ice sheet by observation and model computation. International Association of Hydrological Sciences Publication (Symposia at Yokohama 1993-Snow Cover and its Interactions with Climate and Ecosystems; Processes of Mass and Energy Exchange between the Atmosphere and Polar Surface).

Olesen, O.B. and R.J. Braithwaite. 1989. Field stations for glacier- climate research, West Greenland. In Oerlemans, J., ed. Glacier fluctuations and climatic change. Dordrecht, Kluwer Academic Publishers, 207-218.

Paterson, W. S. B. 1981. The physics of glaciers. Second edition. Oxford, etc., Pergamon Press.

Poggi, A. 1977. Heat balance in the ablation area of the Ampère Glacier (Kerguelen Islands). 7. Appl. Meteorol., 16 (1), 48-55.

Price, A.G. and T. Dunne. 1976. Energy balance computations of snowmelt in a subarctic area. Water Resour. Res., 12(4), 686-694.

Streten, N.A. and G. Wendler. 1968. The midsummer heat balance of an Alaskan maritime glacier. J. Glaciol., 7(51), 431-440.

Wal, R.S.W. van de and J. Oerlemans. 1994. An energy balance model for the Greenland ice sheet. Global and Planetary Change, $\mathbf{9}$, $115-131$.

Wendler, G. and G. Weller. 1974. A heat-balance study on McCall Glacier, Brooks Range, Alaska: a contribution to the International Hydrological Decade. f. Glaciol., 13(67), 13-26.

MS received 27 January 1994 and in revised form 28 June 1994 